\title{
Transitional care of nurses to older adults with artificial pacemaker
}

\author{
Cuidado transicional de enfermeiras ao idoso com marcapasso artificial \\ Atención transitoria de enfermeras a ancianos con marcapasos artificial
}

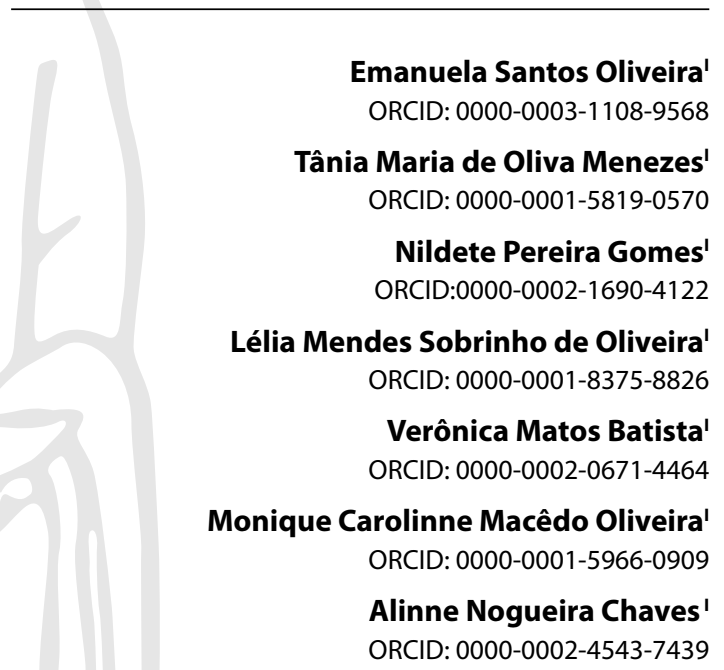

'Universidade Federal da Bahia. Salvador, Bahia, Brazil.

How to cite this article: Oliveira ES, Menezes TMO, Gomes NP, Oliveira LMS, Batista VM, Oliveira MCM, et al. Transitional care of nurses to older adults with artificial pacemaker.Rev BrasEnferm. 2022;75(Suppl 4):e20210192. https://doi. org/10.1590/0034-7167-2021-0192

\section{Corresponding author: \\ Emanuela Santos Oliveira \\ E-mail:emanuolienfa@gmail.com}

EDITOR IN CHIEF: Antonio José de Almeida Filho ASSOCIATE EDITOR: Hugo Fernandes

Submission: 03-14-2021

Approval: 06-26-202

\section{ABSTRACT}

Objective: to understand how the transitional care of nurses to olde adults with artificial pacemaker occurs. Method: a qualitative research, carried out in a philanthropic hospital in the city of Salvador, Bahia, Brazil. Fourteen nurses working in surgical and cardiac inpatient units participated. Data were collected between August and November 2020, through semi-structured interviews, and analyzed using the methodological framework Discourse of the Collective Subject and discussed in the light of Afaf Meleis' theory of transitions. Results: nurses' incipient knowledge about transitional care was identified. It was observed that the nursing discharge report is a facilitating instrument for transitional care. Final considerations: the study pointed out that the transitional care of nurses to older adults with artificial pacemakers does not have a theoretical foundation, reporting as a priority the care with the pacemaker identification card and with the surgical wound.

Descriptors: Transitional care; Nurses; Aged; Pacemaker, Artificial; Patient Discharge.

\section{RESUMO}

Objetivo: apreender como ocorre o cuidado transicional da enfermeira ao idoso com marcapasso artificial. Método: pesquisa qualitativa, realizada em um hospital filantrópico, na cidade de Salvador, Bahia, Brasil. Participaram 14 enfermeiras atuantes nas unidades de internação cirúrgica e cardiológica. Os dados foram coletados entre agosto e novembro de 2020, por meio de entrevista semiestruturada, e analisados pelo referencial metodológico Discurso do Sujeito Coletivo e discutidos à luz da teoria das transições de Afaf Meleis. Resultados: foi identificado conhecimento insipiente das enfermeiras acerca do cuidado transicional. Observou-se que o relatório de alta de enfermagem constitui um instrumento facilitador para a transição do cuidado. Considerações finais:o estudo apontou que o cuidado transicional de enfermeiras ao idoso com marcapasso artificial não possui fundamentação teórica, relatando como prioridade o cuidado com a carteira de identificação do marcapasso e com a ferida operatória.

Descritores: Cuidado Transicional; Enfermeiras e Enfermeiros; Idoso; Marca-Passo Artificial; Alta do Paciente.

\section{RESUMEN}

Objetivo: comprender cómo se produce el cuidado transitorio del enfermero al anciano con marcapasos artificial. Método: investigación cualitativa, realizada en un hospital filantrópico de la ciudad de Salvador, Bahía, Brasil. Participaron 14 enfermeros que laboran en las unidades de internación quirúrgica y cardíaca. Los datos fueron recolectados entre agosto y noviembre de 2020, a través de entrevistas semiestructuradas, y analizados utilizando el marco metodológico Discurso del Sujeto Colectivo y discutidos a la luz de la teoría de las transiciones de Afaf Meleis. Resultados: se identificó el conocimiento incipiente de las enfermeras sobre los cuidados transicionales. Se observó que el informe de alta de enfermería es un instrumento facilitador para la transición asistencial. Consideraciones finales: el estudio señaló que el cuidado transicional de enfermeras al anciano con marcapasos artificiales no tiene un fundamento teórico, reportando como prioridad el cuidado con la tarjeta de identificación del marcapasos y con la herida quirúrgica.

Descriptores: Cuidado de Transición; Enfermeras y Enfermeros; Anciano; Marcapaso Artificial; Alta del Paciente. 


\section{INTRODUCTION}

A study by the Ministry of Health indicates that approximately $33 \%$ of deaths are caused by cardiovascular disease (CVD). These numbers become even greater if we consider the elderly population $^{(1)}$. After the age of 60 , changes in electrophysiological properties are evident, increasing the occurrence of arrhythmias, sinus dysfunctions, atrioventricular blocks and a higher incidence of pacemaker implantation ${ }^{(2)}$.

Artificial pacing is a standard of care in various cardiac conditions, with efficacy in improving survival ${ }^{(3)}$. This stimulation, in addition to saving life, allows patients to achieve a quality of life (QoL) compatible with the population mean ${ }^{(4)}$.

The impacts of pacemaker (PM) use can be both physical and psychological, requiring a redefinition of routine and reorganization of actions and thoughts. Among the most common behavior changes that emerge from this process are resistance to PM implementation, distrust of resoluteness, permanent fear of death, the idea of a weak heart that will make life dependent on a device, as well as the search for an explanation for their adverse health condition, low self-esteem and depression ${ }^{(5)}$.

PM implantation inserts individuals in the context of hospital care. In these circumstances, the elderly person with limitations inherent to senility starts to need support from the health team, contemplating transitional care to meet the new reality. This care is necessary, as it reduces new hospitalizations and optimizes the health-disease process( ${ }^{(6)}$.

Transitional care is configured in actions that guarantee the coordination and continuity of healthcare, in the transfer of patients between different healthcare services or units in the same location ${ }^{(7)}$. It has been highlighted as one of the ways to overcome the fragmentation of care and ensure continuity of care.

Hospital discharge requires planning, preparation, and health education for patients and families, especially for older adults and people with chronic illnesses, who have persistent and ongoing health needs. However, discharge guidelines are sometimes performed mechanically and hurriedly, without considering the conditions and needs of each patient, often provided at the time of leaving the hospital ${ }^{(8)}$.

Insecurity and doubt permeate the new routine of these older adults regarding therapy, rest, and returning to their usual activities. In this context, nursing actions can help to minimize this setback.

Nursing care has mechanisms that enable and guarantee the quality of patient care. In addition, it improves communication between the team and the patient. In this sense, the preparation of a discharge plan by a nurse must be initiated during hospital admission, given that the nursing process does not occur in a linear way, but is interrelated.

The systematization of nursing care (SNC) is the organizing method of nursing work, operationalizing care both in the hospital environment and in the home. Among the steps of SNC, planning stands out as a subsidy for practice of care. In this context, the discharge plan is highlighted as an essential device for the continuity of care at home to promote QoL and prevent readmissions ${ }^{(9)}$. In this context, Afaf Meleis'theory of transitions reiterates the importance of comprehensive care, given the changes suffered by individuals in life, health, relationships and environment in the transition process ${ }^{(10)}$.
The study is justified by the clinical relevance of artificial PM implantation for the rehabilitation and maintenance of individuals' QoL. Therefore, the impacts on public health refer to the rate of hospital readmissions caused by exacerbation of previous CVD and health costs.

Given the above and taking into account the magnitude of PM implantation in the context of longevity, this work will contribute to expand research on this theme, subsidize nursing care regarding the use of PM in hospital-home care, promoting promotion and recovery of individuals' health, aiming to reduce readmission rates. From an academic perspective, there is a scarcity of nursing research on this topic, highlighting the relevance of the study. In Brazil, the advance of investigations about transitional care is insufficient ${ }^{(11)}$. This approach is still little discussed, especially with regard to hospital-home discharge planning, causing fragmentation in care $^{(12)}$.

\section{OBJECTIVE}

To understand how the transitional care of nurses to olde adults with artificial pacemaker occurs.

\section{METHODS}

\section{Ethical aspects}

The research followed the ethical and legal precepts with regard to Resolution $466 / 12$ and its complements. The study guaranteed participants' anonymity, using Greek goddesses codenames as a way to honor nurses for their feminine strength, as they are considered powerful, courageous women, with multiple motivations and abilities, linked to love, wisdom and divinity.

\section{Study design}

This is a qualitative research, which emphasizes the understanding of processes, not only focusing on results, including the uniqueness in a broader historical and social context ${ }^{\left({ }^{(13)}\right.}$, based on Afaf Meleis'a Transition Theory ${ }^{(10)}$, which denotes the transition as changes in individuals' health status, role relationships, expectations or abilities. It understands the transition as a passage from one state, condition or from one place to another, involving a psychological process of adaptation to a change that requires interior reorganization to adapt to new circumstances. This theory encompasses three components: nature of transitions, conditions for transition, and response patterns, with a healthy transition being determined by response patterns through process and outcome indicators ${ }^{(14)}$. The study was conducted and structured with reference to the COREQ (COnsolidated criteria for REporting Qualitative research) ${ }^{(15)}$.

\section{Study setting}

This study was carried out in a philanthropic hospital in Salvador, Bahia, Brazil, recognized by the Ministry of Health as a center of high complexity, with a reference in cardiology and other specialties, with PM implantation one of the procedures 
performed regularly. The survey was carried out in inpatient units that receive surgical and cardiac patients.

\section{Data source}

Research participants consisted of 14 nurses, who provide assistance in inpatient units specializing in cardiology and surgery. The choice was based on the fact that nurses admit patients for the surgical procedure and provide guidelines for hospital discharge. Nurses with more than six months of experience and with a fixed scale in the sector were excluded. Those who were away from the service for any reason during the interview period were excluded.

\section{Data collection and organization}

The collection took place between August and November 2020 through semi-structured interviews, using closed questions, covering demographic and social data and three open questions for approach and investigation (What do you understand about transitional care? When do you start planning for discharge? What care guidelines do you provide to the elderly person with cardiac PM during hospitalization for the hospital-home transition?). As a way to improve the conduct of the interviews, before applying the instrument to nurses, a test was carried out with a pilot group and discussed with the authors. The interviews were conducted by the first author and carried out in private rooms within each ward, with only the presence of the researcher and the individual interviewee, in order to guarantee the confidentiality and privacy of participants, with a duration ranging from five to 15 minutes. Participants were selected by sampling, according to the area of activity and respective units that care for patients in the PM implantation process. The interviews were carried out face to face, with no refusal or withdrawal at any time. Data were recorded with the aid of a digital recorder; then they were transcribed in full.

\section{Data analysis}

Data were organized anchored in the Discourse of the Collective Subject (DCC) methodological framework. In this context, individual opinions or expressions that have similar meanings are grouped into general semantic categories, in order to form a summary statement with contents, written in the first person singular, as if it were a collectivity speaking in the person of an individual ${ }^{(16)}$.

The construction of DCS consists of the use of instruments such as: key expressions (KE), defined as continuous or fragmented segments, which aim to expose the content of an answer to a research question, highlighting the essence of the testimony that refers to the idea central. Central ideas $(\mathrm{Cl})$ synthesize the meaning presented in $\mathrm{KE}^{(17)}$. Data analysis was performed by identifying nurses' opinions, with similar meanings characterizing $\mathrm{Cl}$ and KE. These data were grouped into categories, according to similarity, giving rise to the collective discourse.

In the methodological follow-up, analysis of verbal material made known by nurses made it possible to extract $\mathrm{Cl}$ and $\mathrm{KE}$ from the statements, enabling the composition of the synthesisdiscourse or DCS.

\section{RESULTS}

The study included 14 nurses, all female, with a mean age of 37 years. Most were single $(n=11)$, with a graduate education level $(n=13)$, training time of 10 years above $(n=9)$, length of experience in the unit with a cardiac and surgical profile above 05 years $(n=9)$.

The collective discourses of nurses in the care of older adults with cardiac PM in the hospital-home transitional process emphasize the priority of care from the perspective of these professionals, highlighting the weaknesses of care planning. Intervening factors that influence the dynamics of transitional care are highlighted, enhanced by the incipient knowledge of participants about the approach. However, the importance of qualified care to meet older adults' needs in this context is highlighted, given the specificity and importance of the procedure for maintenance and QoL.

Chart 1 shows the $\mathrm{Cl}$ of nurses' discourses on transitional care for older adults with artificial PM.

Chart 1 - Central ideas of nurses' discourses on transitional care for older adults with artificial pacemakers, Salvador, Bahia, Brazil, 2020

\begin{tabular}{|c|l|}
\hline NUMBER OF ORDER & CENTRAL IDEA \\
\hline 1 & 1 Start of discharge plan \\
\hline 2 & 2 Continuity care \\
\hline 3 & $\begin{array}{l}\text { 3 Care guidelines } \\
3.1 \text { Pacemaker identification card } \\
3.2 \text { Operative wound }\end{array}$ \\
\hline
\end{tabular}

\section{IC- 1 Start of discharge plan}

The speeches show that most nurses initiate hospital discharge planning upon admission and use a multidisciplinary discharge plan as an instrument. However, they state that the length of stay of patients in these units is short between the inpatient unit and the operating room, increasing the speed of the guidelines.

Discharge guidelines start from admission, I end up giving care guidelines very quickly, because the hospital stay is very short. The patient comes in one day, has the PM implanted and leaves the next. I start preparing them from admission. The placement of PM is a quick procedure, so it has to be started from the moment it arrives. When I go to collect his data, I already pass on some information [...] when he arrives, I already guide him. I already plan his discharge. When the patient is admitted, I apply the multidisciplinary patient discharge protocol. So, our schedule starts from when he enters the hospital, when he is admitted! The care plan is made from the moment the patient is admitted. I've already started an orientation about what's going to happen to him. Usually, when the PM is going to be implemented, it doesn't take long, it's a matter of 02 days. I already plan from the beginning. (Artemis; Athena; Demeter; Hestia; Hemera; Thalassa; Tethys; Rhea)

However, although most nurses start planning for hospital discharge upon admission, there is a considerable number of professionals who provide guidance in the post-procedure or when hospital discharge is imminent. 
When the patient returns from surgery, I plan for discharge, advising on the care that he will have with PM. The theory, sometimes, is not very consistent with our practice, this report is made on the day of hospital discharge. His stay here doesn't take long, a day at most. Deploys PM and next day he leaves. So, in practice, I usually do this orientation when he is leaving[...] when he is discharged. I guide the patient when he arrives from the operating room [...] I start the discharge planning from when the patient returns from surgery, in the immediate postoperative period. When he returns, all the care I do, I let both the family and him know. I'm already starting to act tall myself. He is usually discharged the next day. From the moment the doctor informs that he is going to discharge the patient, I already make the discharge plan. (Hera; Gaia; Nix; Phoeby; Mnemosyne; Thea)

\section{IC 2 Continuity care}

Nurses' discourses regarding transition care reveal that most perform this care in a small way, despite having insufficient technical knowledge on the subject. In this regard, it is observed that the answers infer more deductive character than scientific.

I understand it as the moment when the patient leaves the hospital for home. That transition in which he will no longer take care of the team to carry out care alone or with the help of a family member. It is the care that has already started, which we will continue and guide for the post-secondary period, that is, at home or in a nursing home. When a certain person is in one situation and he will move on to another one that needs some guidance. It is the care that I teach to the patient and the family so that they have autonomy, to give continuity at home. I think transition care is care that involves both the pre, trans and post procedure. Care provided from the moment the patient leaves the hospital unit and goes home. Transition, for me, that's it, between one thing and another. [...] that care that I start at the hospital preparing the patient and family for home care. I understand that they are continuity care. (Artemis; Athena; Demeter; Hestia; Gaia; Nix; Phoeby; Rhea)

\section{IC 3 Care guidelines}

Regarding the guidelines for care during hospitalization for the hospital-home transition, the speeches report that nurses' guidelines consist predominantly of information regarding the PM's identification card, as well as the care for surgical wounds. Guidance regarding warning signs about possible complications is very remote, emphasizing, in nurses' discourses, the priority of care for the surgical wound and the use of PM identification card.

\section{IC 3.1 Pacemaker identification card}

The guidelines start with the documentation, he has to keep using his card. [...] I always advise to keep the card as a document, because the card will contain the data referring to the device that was implanted. Usually, when the patient arrives, the first thing I do is remove the manual from the card and hand it to the patient or family member and ask them to read the instructions. I advise whenever he goes to environments that contain revolving doors, take the PM card identification. I hand over the card containing all the information related to the pacemaker and make it clear that you need to be careful with those documents. I ask the patient and family to read the manual and highlight the information they are curious about, whether they can use a cell phone, elevator, revolving door. Always carry the pacemaker identification card, because there are places that can prevent it from entering. (Artemis; Athena; Hera; Hestia; Gaia; Hemera; Tethys; Mnemosyne; Thea; Rhea)

\section{IC 3.2 Surgical wound}

I advise to perform the dressing. Generally, I advise to remove the dressing after 02 days, wash it with soap and water and dry it with a clean cloth. As it is a simple surgery, l ask him to keep the dressing for a couple of days after the surgery, and then he can leave it uncovered, if there is no sign of secretion. You can take a normal bath with soap and water and dry thoroughly. It's a lesion that is usually dry and doesn't have many complications. I advise that if you are bleeding, still wash with soap and water and keep covered until it stops bleeding. It is a surgical incision, so I keep this dressing covered, but l leave guidance for the next day, at the time of the bath, to remove this dressing, wash the area with soap and water. I usually provide the chlorhexidine and then apply it to the spot. Observe signs of infection if it is draining secretion, if you have hyperemia, if you will notice any edema, ecchymosis beyond the common. At first, I advise you to apply the dressing once a day, keep the dressing always dry, covered for the first 24 hours. (Artemis; Athena; Demeter; Hera; Hestia; Gaia; Nix, Hemera; Thalassa; Phoeby; Tethys)

In addition to taking care of the PM's portfolio and the surgical wound, guidelines are identified despite possible complications after PM implantation.

Ilet him know about signs and symptoms he may experience and what to do if they do. If you have any unusual signs and symptoms, you should go to the hospital. I advise that, if you feel something, feel any weakness, dizziness, be quiet, do not walk and call your family member [...]. The family member already knows that if he feels anything he should go back to the emergency room, because he is in the postoperative period, he should inform the assistant doctor that he is having a little problem. I advise him to talk to the family if he feels uncomfortable to be referred to the emergency room, because he has older adults who hide. (Tethys; Mnemosyne; Rhea)

Considering Afaf Meleis' theoretical approach, nursing as a science is responsible for meeting the multiple focuses of interest and intervening in the process, in order to facilitate the transition of people, family and community through care centered on experiences in transition, resulting in health and well-being of individuals ${ }^{(14)}$. Through the results of this study, the fragility in the performance of nurses to cover transitional care in its entirety is observed, as this theory postulates.

\section{DISCUSSION}

The study presented has female representation, reaffirming what research emphasizes about gender issues in the field of nursing. The nursing team is predominantly female, consisting of $84.6 \%$ of women ${ }^{(18)}$. 
Nurses' discourse on care for older adults with artificial PM in the hospital-home transition reveals the relevant aspects of transitional care in this perspective, highlighting some gaps in this care, corroborated in the literature as weaknesses in this process. One of the complicating factors for the adequacy of this care is the lack of studies on transitional care and, therefore, the insufficiency of nurses' knowledge about the theme observed in the discourses.

The applicability of transitional care is still a process under construction and adaptation in several countries, with a lack of research, especially in $\mathrm{Brazi}^{(8)}$. The literature shows nurses as the professionals most involved in transitional care from hospital to home; however, there is little knowledge of this professional on the subject and lack of recognition of transition of care as one of their attributions ${ }^{(11)}$.

Anchored in Afaf Meleis' theory of transitions, which defends "transition" as a central concept in nursing and in this perspective, it is emphasized that health and well-being result from the nursing intervention ${ }^{(19)}$, understanding the inefficiency of continuity care, given the evidence of nurses' unpreparedness in the context of transition.

A study carried out with 40 transplant patients in Brazil and Spain who were undergoing outpatient follow-up showed that a qualified transition requires early discharge planning, carried out upon admission. Hospital discharge planning consists of nurses' guidance on various aspects of care to be practiced at home. Given the breadth of this care, it is necessary to start before discharge, in order to ensure that users and caregivers have time to assimilate the necessary information for continuity at home ${ }^{(20)}$.

Although, in the speeches, most nurses report that they perform this preparation at the entrance of patients, there is still a significant number of professionals who do not work in the same way. Thus, these guidelines are given in the immediate postoperative period or when these old adults are leaving the hospital unit. The discharge guidelines provided by nurses, for the most part, are carried out in the imminence of hospital discharge, without considering the individual conditions and needs of patients and families, making it difficult to understand and compromise care ${ }^{(21)}$.

To facilitate the management of care, nurses use SNC, and one of its stages is the discharge plan, which provides subsidies to qualify continuity of care. SNC helps to mitigate complications, develop a care plan, prepare for discharge, in addition to promoting patient and family guidance for home care. Through the discharge plan, it is possible to facilitate patients' transition in health services and ensure continuity of care $\mathrm{e}^{(22)}$.

The nursing discharge report, currently also known as continuing care report, is a facilitating document in discharge planning, as mentioned by nurses in the speeches. This report includes the fundamentals of the nursing process for patient admission, ensuring continuity of care and contributing to the monitoring of patients ${ }^{(23)}$. However, the importance of nurses' role is emphasized to clarify the discharge report to patients and family/caregiver regarding the techniques, procedures and support network, in order to ensure the continuity of this care at home.

Meleis' theory of transitions proposes that nurses act to prevent risks, improve well-being, maximize functioning and reproduce self-care activities. In this sense, it integrates a linear sequence of actions with assessment, planning and implementation, covering the entire transition period; in this way, it early detects difficulties at critical points in the process ${ }^{(24)}$. To implement this ideal care, nursing has the high labor demand and consequent lack of time as intervening.

Old adult patients undergoing surgical treatment, such as definitive cardiac PM implantation, require specific care at home. The attention of professionals must be focused on the various aspects that involve this approach and that interfere with the QoL of these individuals, whether physical, social, emotional, psychological or spiritual. For patients with an indication of PM, several values are assumed based on the perception of a weak heart, depending on the functioning of a device to maintain life ${ }^{(25)}$. These individuals generally experience feelings of anxiety, depression and fear, with negative perspectives regarding the future ${ }^{(26)}$.

Care and guidance to patients with definitive PM are specific and facilitate acceptance and adaptation to the new lifestyle. In this way, nurses act fundamentally, as they are in continuous contact with these individuals, playing the role of a health educator, with a view to providing the necessary guidance, enabling the realization of self-care and coping with difficulties in the short and long term, contributing to independence, autonomy and improvement of QoL ${ }^{(27)}$. However, in this study, it is noted that nurses interviewed adhere to care related to PM identification card and PM store, without considering the other aspects, also relevant to recovery and rehabilitation.

Another important aspect to be considered by nurses refers to guidance on possible complications arising from PM implantation in older adults in the postoperative period at home. The postoperative period comprises a delicate period for patients and families, as it involves psychological, emotional and physical aspects that influence recovery. At this stage, health guidance should be used in order to develop patients' independence during post-surgical recovery and provide knowledge that allows for the early identification of signs and symptoms of possible complications ${ }^{(28)}$. The interviewees in this research mentioned little guidance about complications, in addition to the lack of clarification on how to conduct the return of these patients and who to contact in case of need.

Given the complexity of cardiovascular surgery, there are high rates of hospital readmission. Thus, transitional care becomes essential and requires planning and health education to ensure home care. In this context, nurses actin the coordination and execution of transitional hospital-to-home care ${ }^{(29)}$.

Meleis' theory reiterates the role of nurses as the main caregivers of clients and family members in the transition process. In this sense, they are the ones who prepare patients for the imminent transitions, facilitating the learning of new skills related to health and disease experiences ${ }^{(30)}$.

The care guidelines for older adults with PM mentioned by nurses in this study do not cover information about the implantable electronic cardiac device (IECD) and this reflects on nurses lack of knowledge about the functioning and technologies that involve the PM. Clinical practice evidences the lack of knowledge of patients and professionals about the safety and resources involved in the IECD technology ${ }^{(31)}$. According to the literature, 
nurses are responsible for understanding the functioning of the device, identifying electrocardiographic tracings, the pathophysiological process of the disease, as well as having comprehensive technical knowledge ${ }^{(32)}$.

In this study, nurses report the excess demand associated with the short period of stay of these patients in the inpatient units as obstacles in the transition of this care, since information is transmitted quickly. In their routine, nurses have little availability to guide patients and their families in a timely manner, prior to hospital discharge ${ }^{(33)}$. Discharge guidelines are restricted, mostly performed by doctors and nurses, in a reduced time without considering the completeness of patient needs ${ }^{(34)}$.

Meleis' theory of transitions emphasizes the importance of strategies used by nurses in the context of older adults, considering the increase in this population, aiming to care for and support these individuals to achieve a healthy life ${ }^{(35)}$.

Given this reality, nursing care for older adults with cardiac PM requires comprehensive knowledge and specific skills that support the preparation of these patients for the safe practice of self-care at home, reducing hospital readmission rates. The care of patients undergoing cardiac surgery requires nurses to intensify knowledge and care based on technical-scientific, surgical, emotional and psychosocial needs, enabling the quality of the postoperative period ${ }^{(36)}$. From this perspective, nurses intervene by favoring the health education of patients and caregivers, contributing to their recovery ${ }^{(37)}$. The holistic care that encompasses the biopsychosocial-spiritual aspects is still a process under development in the context of Brazilian nursing, especially with regard to PM implantation, due to the short period of hospital stay. However, it is known that it is possible to start this care early, extending it to post-discharge follow-up, as it already occurs in other countries.

Given the above, Afaf Meleis' theory of transitions supports this study, given that the elderly, when submitted to an artificial PM implantation, permeates through distinct phases of losses, benefits and adaptation of patients and families, denoting changes in the state of health and early preparation facilitates the transition experience.

\section{Study limitations}

Considering that the study was developed in the inpatient units that receive surgical and cardiac patients from a philanthropic hospital in Salvador, Bahia, Brazil, it makes it impossible to generalize the results to all nurses. However, this study can be replicated in other groups of nurses who experience similar dynamics to those of the participants in this research, enabling the discussion of information as well as improvement of service and quality of care.

\section{Contributions to nursing and health}

The results of this research contribute to expand the knowledge of nurses regarding transitional care for older adults by pointing out gaps that need to be remedied and/or minimized, in order to promote specific care for this audience through future actions that help in operationalization of SNC with regard to transitional care. Moreover, it is expected that the results presented will support new scientific production supported by technologies aimed at promoting transitional care for nurses to old adults with artificial PM.

\section{FINAL CONSIDERATIONS}

The study showed that nurses involved in transitional care for older adults with artificial PM exercise this care without theoretical foundation, not considering some aspects that make up the integrality of individuals; thus, they technically emphasize the care directed to the cardiac device, such as the use of a PM identification card and surgical wound. Furthermore, the rapidity of the guidelines, justified by the high demand for practice and the length of stay of these patients in the units, is one of the weaknesses for transitional care, given the importance of completeness of the guidelines in order to ensure continuity of care.

\section{REFERENCES}

1. Dutra DD, Duarte MCS, Albuquerque KF, Lima AS, Santos JS, Souto HC.Doenças cardiovasculares e fatores associados em adultos e idosos cadastrados em uma unidade básica de saúde. Rev Pesqui: Cuid Fundam. 2016;8(2):4501-09. https://doi.org/10.9789/2175-5361.2016. v8i2.4501-4509

2. Esquenazi D, Silva SRB, Guimaraes MAM. Aspectos Fisiológicos do envelhecimento humano e quedas em idosos. RHUPE. 2014;13(2):11-20. https://doi.org/10.12957/rhupe.2014.10124

3. Haugaa KH, Potpara TS, Boveda S, Deharo J, Chen J, Dobreanu D. Patients' knowledge and attitudes regarding living with implantable electronic devices: results of a multicentre, multinational patient survey conducted by the European Heart Rhythm Association. Europace. 2018;20(2):386-91. https://doi.org/10.1093/europace/eux365

4. Mota WH. Estimulação cardíaca artificial e suas implicações na enfermagem. J Health Biol Sci. 2018;6(1):100-07. https://doi. org/10.12662/2317-3076jhbs.v6i1.1149.p100-107

5. Bergmann ARN, Souza LV, Scorsolini-Comin, F, Santos MA. A vida por um fio: percepções sobre o implante de marcapasso cardíaco permanente. Rev Subj. 2016;16(1):131-43. https://doi.org/10.5020/23590777.16.1.131-143

6. Menezes TMO, Oliveira ALB, Santos LB. Cuidado de Transição Hospitalar a pessoa idosa: revisão integrativa. Rev Bras Enferm. 2019;72(Suppl 2):307-15. https://doi.org/10.1590/0034-7167-2018-0286

7. Colleman EA, Boult C. American Geriatrics Society Health Care Systems Committee. Improving the quality of transitional care for persons with complex care needs. J Am Geriatr Soc. 2003;51(4):556-7. https://doi.org/10.1046/j.1532-5415.2003.51186.x 
8. Weber LAF, Lima MADS, Acosta AM, Marques GQ. Transição do cuidado do hospital para o domicílio: revisão integrativa. Cogitare Enferm. 2017;22(3):1-11. https://doi.org/10.5380/ce.v22i3.47615

9. Nunes ECDA, Menezes NL. Sistematização da alta de enfermagem: uma análise fundamentada em Roy. Cogitare Enferm. 2016;21(2):01-09. https://doi.org/10.5380/ce.v21i2.45875

10. Meleis Al. Theorical nursing: development e progress. 4. Ed. Philadelphia: Lippincott; 2007. 832p.

11. Acosta AM, Câmara CE, Weber LAF, Fontenele RM. Atividade do enfermeiro na transição do cuidado: realidades e desafios. Rev Enferm UFPE. 2018;12(12):190-7. https://doi.org/10.5205/1981-8963-v12i12a231432p3190-3197-2018

12. Lima MADS, Magalhães AMM, Oelke ND, Marques GQ, Lorenzini E, Weber LAF, et al. Estratégias de transição de cuidados nos países latinoamericanos: uma revisão integrativa. Rev Gaúcha Enferm. 2018;39:e20180119. https://doi.org/10.1590/1983-1447.2018.20180119

13. Minayo MCS, Guerriero ICZ. Reflexividade como éthos da pesquisa qualitativa. Ciênc Saúde Coletiva. 2014;19(4):1 103-12. https://doi. org/10.1590/1413-81232014194.18912013

14. Silva R, Carvalho A, Rebelo L, Pinho N, Barbosa L, Araújo, T, et al. Contributos do referencial teórico de Afaf Meleis para a enfermagem de reabilitação. Rev Investig Enferm [Internet]. 2019 [cited 2021 May 20];35-44. Available from: https://www.researchgate.net/ publication/337313131_Contributos_do_referencial_teorico_de_Afaf_Meleis_para_a_Enfermagem_de_Reabilitacao

15. Tong A, Sainsbury P, Craig J. Consolidated criteria for reporting qualitative research (COREQ): a 32-item checklist for interviews and focus groups. Int J Qual Health Care [Internet]. 2007 [cited 2020 Jul 01];19(6):349-57. Available from: https://academic.oup.com/intqhc/ article/19/6/349/1791966

16. Lefreve F, Lefreve AMC. Discurso do sujeito coletivo: representações sociais e intervenções comunicativas. Texto Contexto Enferm. 2014;23(2):502-50. https://doi.org/10.1590/0104-07072014000000014

17. Almeida GBS, Paz EPA, Silva GA. Representações sociais sobre hipertensão arterial e o cuidado: o discurso do sujeito coletivo. Acta Paul Enferm. 2011;24(4):459-65. https://doi.org/10.1590/S0103-21002011000400003

18. Conselho Federal de Enfermagem. Pesquisa inédita traça perfil de enfermagem [Internet]. COFEN; 2015[cited 2020 Jul 01]. Available from: http://www.cofen.gov.br/pesquisa-inedita-traca-perfil-da-enfermagem_31258.html

19. Ribeiro OMPL, Martins MMFPS, Tronchin DMR, Forte ECN. O olhar dos enfermeiros portugueses sobre os conceitos metaparadigmáticos de enfermagem. Texto Contexto Enferm. 2018;27(2):1-9. https://doi.org/10.1590/0104-070720180003970016

20. Nunes SS, Montesinos MJL, Pedroso VSM, Tolfo F, Bick MA, Siqueira HCH. Adesão às orientações do enfermeiro para cuidado domiciliar do transplantado de medula óssea na perspectiva ecossistêmica. Texto Contexto Enferm. 2020;29:e20180310. https://doi. org/10.1590/1980-265x-tce-2018-0310

21. Martins KP, Costa KNF, Oliveira DST. Atuação do enfermeiro no preparo para a alta hospitalar de pacientes cirúrgicos. Rev Pesqui: Cuid Fundam. 2015;7(1):1756-64. https://doi.org/10.9789/2175-5361.2015.v7i1.1756-1764

22. Costa MFBNA, Ciosak SI, Andrade SR, Soares CF, Pérez EIB, Bernadino E. Continuidade do cuidado da alta hospitalar para atenção primária a saúde: a prática espanhola. Texto Contexto Enferm. 2020;29:e20180332. https://doi.org/10.1590/1980-265X-TCE-2018-0332

23. Seva-Llor AM, Montesinos MJL, Ortega CB, Cecagno D, Roche FP. Relatório de Enfermagem no hospital. Acta Paul Enferm. 2015;28(2):101-6. https://doi.org/10.1590/1982-0194201500018

24. Costa LGF. Visitando a teoria das transições de Afaf Meleis como suporte teórico para o cuidado de enfermagem. Enferm Bras. 2016;15(3):137-45. https://doi.org/10.33233/eb.v15i3.181

25. Neves RRS, Silva IS. A qualidade de vida de pacientes com Marcapasso. In: Anais do VI SIMPAC, 2016; Viçosa-MG, Brasil. Univiçosa; 2016;8(1):50-4.

26. Alievi GJP, Roman EP, Lise AMR. Aspectos que envolvem a ansiedade em pacientes pré e pós-operatórios da cirurgia cardíaca: as eventuais complicações e o prognóstico clínico em uma abordagem teórica. Rev Thêma Sci[Internet]. 2017[cited 2020 Dec 10];7(2):197-208. Available from: http://www.themaetscientia.fag.edu.br/index.php/RTES/article/view/770

27. Santos JEM, Brasil VV, Moraes KL, Cordeiro JABL, Oliveira GF, Bernardes C, et al. Legibilidade de prospecto facilitador e letramento em saúde de indivíduos com marcapasso. Rev Bras Enferm. 2017;70(3):661-7. https://doi.org/10.1590/0034-7167-2016-0336

28. Santos FDRP, Silva JO, Nunes SFL, Pascoal LM, Lima PM. Relação entre orientação em saúde e complicações no pós-operatório de cirurgias torácicas e abdominais altas. Rev Pesqui: Cuid Fundam. 2020;12:253-7. https://doi.org/10.9789/2175-5361.rpcfo.v12.8321

29. Santos TL, Laprano MGG, Conceição AP. Orientações de alta hospitalar para o desempenho do autocuidado após a cirurgia cardíaca: revisão integrativa. Rev Baiana Enferm. 2020;34:e35284. https://doi.org/10.18471/rbe.v34.35284

30. Meleis Al, Sawyer LM, Im EO, Messias DKH, Schumacher K. Experiencing transitions: an Emerging Middle Range Theory. ANS. 2000;23(1):1228. https://doi.org/10.1097/00012272-200009000-00006

31. Vianna MS, Silqueira SMF, Luz AR, Ignácio FL, Correa AR, Mattos SS. Plano de orientações a pacientes após o implante de dispositivos cardíacos eletrônicos implantáveis. Relampa [Internet]. 2014[cited 2020 Dec 5];27(1):27-33. Available from: https://jca.emnuvens.com.br/ jca/article/view/2442.

32. Vieira TC, Simonetti SH, Kobayashi RM. Validação das competências do enfermeiro nos cuidados com portadores de marca-passo. Nursing[Internet]. 2019[cited 2020 Nov 5];22(255):3095-3100. Available from: https://pesquisa.bvsalud.org/portal/resource/pt/biblio-1025985 
33. Coli, M; Zani, AV. Validação de um plano de alta de enfermagem para gestantes e puérperas de alto risco. Rev Min Enferm. $2016 ; 20$ : e934. https://doi.org/10.5935/1415-2762.20160004

34. Fontana G, Chesani FH, Nalin F. Percepções dos profissionais da saúde sobre o processo de alta hospitalar. UNIFEBE[Internet]. 2017 [cited 2021 Jan 20];1(21). Available from: https://periodicos.unifebe.edu.br/index.php/revistaeletronicadaunifebe/article/view/491

35. Meleis Al. Trangenstein PA. Facilitating Transitions: redefinition of the Nursing Mission. In: Transitions Theory: Middle-Range and SituationSpecific Theories in Nursing Research and Practice. New York: Springer Publishing Company; 2010.

36. Santos APA, Laus AM, Camelo SHH. O trabalho da enfermagem no pós-operatório de cirurgia cardíaca: uma revisão integrativa. ABCS Health Sci. 2015;40(1):45-52. https://doi.org/10.7322/abcshs.v40i1.703

37. Malheiro IC, Carmo TG, Cavalcante ACD, Flores PVP. Intervenções de enfermagem no pós-operatório de cirurgia cardíaca. Res Soc Dev. 2020;9(7):1-18. https://doi.org/10.33448/rsd-v9i7.4080 